\title{
KAUM LGBT DALAM SEJARAH PERADABAN MANUSIA
}

\author{
MUHAMAD TISNA NUGRAHA \\ Dosen Fakultas Tarbiyah dan Ilmu Kependidikan (FTIK) \\ Institut Agama Islam Negeri (IAIN) Pontianak \\ tisnanugraha2014@yahoo.com
}

\begin{abstract}
The existence of lesbian, gay, bisexual, or transgender (in Indonesia known as LGBT) has become a sexual problem ini human's life. These minority people considerably have a sexual deviance in their life. Therefore, sometimes, they are discriminated and violated by people who dislike their existence. Eventhough, on the other side, every man has an affinity rights in Law. Besides, LGBT is not an epidemic disease in society entirely. Some of them has contributed in the historical event in the past. Thus, through this artide, the writer would present the information of LGBT's life from historical and religious perspective.
\end{abstract}

\section{Keywords: LGBT, History, Civilization}

\section{PENDAHULUAN}

Lesbian, gay, biseksual dan transgender atau sejak tahun 1990-an dikenal dengan istilah LGBT. Merupakan revolusi perilaku seksual umat manusia menjelang akhir zaman. Keberadaan mereka adalah sebuah klaim kelompok kepada masyarakat luas, dalam rangka untuk memperoleh pengakuan dan legitimasi terhadap keanekaragaman budaya seksual dan gender yang ada pada kelompoknya.

Bagi orang Indonesia yang masih memegang teguh budaya luhur ketimuran, kaum Lesbian, Gay, Biseksual dan Transgender (LGBT) masih dipandang sebagai suatu yang ganjil dan belum dapat diterima secara nalar. Terlebih, sedikit sekali yang dapat diketahui tentang mereka, disamping dari aktivitasnya yang masih tertutup. Namun, suka atau tidak suka, orang-orang dengan kecenderungan seksual yang berbeda seperti yang terdapat pada kaum LGBT memang ada dalam kehidupan, bahkan diantaranya mungkin ada di lingkungan keluarga dan tetangga sekitar kita.

Manusia normal, tentunya akan melakukan perilaku hubungan normal (PHN) serta memiliki orientasi seksual terhadap lawan jenisnya. Seperti misalnya, seorang pria yang tertarik pada wanita atau sebaliknya seorang wanita tertarik pada pria. Mereka ini kemudian disebut dengan kaum hetroseksual. Lain halnya dengan kaum lesbian dan gay, penyuka sesama jenis atau dahulu popular dengan sebutan kaum homoseks. Mereka tidak memiliki kecenderungan seksual seperti itu. Mereka justru lebih tertarik serta merasa nyaman dengan jenisnya. Aktivitas inilah yang kemudiaan berlanjut pada hubungan seksual sesama jenis. Para pria homosesks tertarik pada sesama pria, mereka ini lazim disebut gay. Begitu pula, para wanita homoseks tertarik pada sesama wanita, mereka lazim disebut lesbian. ${ }^{1}$

Derasnya arus globalisasi yang didukung dengan penguasaan teknologi informasi dan komunikasi. Menyebabkan penyebaran kaum LGBT juga semakin berkembang. Diantara mereka ada yang hidup sebagai pelaku aktif, pelaku pasif, maupun sebagai korban kekerasan seksual

11 Abu Ameenah Philips dan Zafar Khan, Islam dan Homoseksual, (Jakarta: Pustaka Zahra. 2003), hlm. 75-76. 
(sodomi). Bahkan dalam banyak kasus kriminal pencabulan anak, korban kekerasan seksual (sodomi) cenderung menjadi pelaku sodomi di kemudian hari seperti yang terjadi pada Robot Gedek, pria paruh baya yang mengemparkan pemberitaan publik Indonesia di tahun 1996, karena ulahnya meyodomi banyak anak laki-laki. Dulunya ia sendiri pernah menjadi korban sodomi. Hal ini seperti dalam film-film zombie, dimana perilaku homoseksual akan terus mencari korban baru untuk menyebarkan penyakitnya.

\section{MEMAKNAI LGBT DALAM KEHIDUPAN}

LGBT adalah istilah modern yang merujuk kepada gabungan empat kumpulan perilaku yang dipandang melawan kodrat dan menolak ketentuan Tuhan. Namun, pada kenyataanya masingmasing bagian dalamLGBT memiliki ciri khas, tujuan dan identitas yang berbeda. Sehingga LGBT hanya dapat diselesaikan dengan penanganan yang berbeda sesuai dengan pengelompokannya.

Meskipun LGBT pada awalnya mulai berkembang dari benua Afrika, Eropa dan Amerika. Namun tidak semua orang yang telah terindentifikasi merupakan bagian dari LGBT setuju dengan istilah tersebut. Misalnya, bagi kaum transgender, transeksual dan kaum yang masih mempertanyakan identitas seksualnya, justru lebih memilih untuk melakukan perlawanan melalui style dan metode pergerakannya sendiri dibandingkan bergabung dengan kaum LGBT.

Selain itu penggunaan istilah LGBT sebenarnya lebih kepada sebuah strategi mempersatukan kelompok-kelompok perilaku menyimpang dalam satu wadah kekuatan yang sama, sehingga dari cara ini diharapkan mampu menarik simpati dan pengakuan dari pemerintah dan masyarakat luas meskipun sebenarnya jumlah mereka di Indonesia pada saat ini terhitung masih amatlah sedikit.

Adapun definisi dari istilah LGBT berdasarkan kelomponya yaitu, (1) lesbian yang dapat diartikan sebagai golongan indvidu yang dilahirkan secara biologis sebagai wanita, namun tertarik kepada wanita yang lain dari segi kecenderungan perasaannya maupun keinginan seksualnya. (2) gay adalah golongan yang dilahirkan secara biologis sebagai lakilaki, namun tertarik kepada sesama laki-laki yang lain, baik dari segi kecenderungan perasaannya maupun keinginan seksualnya. (2) Biseksual adalah seseorag yang mempunyai kecenderungan untuk tertarik kepada lakilaki maupun perempuan pada saat bersamaan. Sehingga kaum biseksual dapat menjalankan aktivitas seksual dengan dua orang yang berlainan kelamin tanpa merasa risih dan terganggu dengan indentitasnya. (4) transgender berbeda dengan golongan gay, lesbian dan biseksual karena golongan transgender tidak berorientasi pada dominasi kecenderungan perasaan maupun seksual pada sesama jenis, melainkan lebih kepada aspek identitas diri.

Golongan transgender biasanya mengindentifikasi dirinya dengan identitas sejati yang dianggap bertentangan sejak lahir. Dimana seorang yang lahir sebagai laki-laki namun nalurinya dan perwataknnya justru sebagai seorang perempuan dan berkeinginan merubah penampilan fisik mereka menjadi perempuan yang biasanya ditempuh dengan mendandani diri (makeup) layaknya perempuan ataupun yang terekstrim dengan jalan melakukan operasi pelastik. Hal ini begitu juga sebaliknya bagi perempuan yang naluri ilmiahnya cenderung adalah laki-laki. Mereka juga akan melakukan hal yang sama, Hanya saja, testis yang dikembangakan dalam teknologi ilmu kedokteran bedah plastik saat ini tidak dapat berfungsi sebagaimana mestinya.

Persoalan yang dimunculkan atas dasar jenis kelamin, identitas seksual, tidak hanya terbatas pada maskulinitas dan feminitas, tetapi juga "penyimpangan" dari keduanya. Pada masyarakat liberal dewasa ini, kelompok-kelompok subaltern seperti lesbianism, gay, dan biseksual menuntut 
hak-hak politisnya. Kenneth Sherrill dalam penyelidikannya di Amerika mengungkapkan bahwa gerakan politik kaum gay, lesbianism, dan biseksual meliputi tuntutan-tuntutan mereka akan eksistensi (pengakuan), hak-hak mendapat perlindungan keamanan, perlindungan kesehatan, dan akhir-akhir ini adalah tuntutan akan keterwakilan mereka di parlemen. ${ }^{1}$ Ilmu sosial modern saat ini juga masih mengacu pada konsep deklarasi kemerdekan yang diusung oleh kounitas LGBT berkembang dan berjuang menolak sudut marginalitas untuk mendapat hak serta kebebasan yang lebih luas dari pada aspek moral dan perundangan. ${ }^{2}$

Pada masyarakat liberal, gerakan penyimpangan seksual muncul begitu saja sebagai sebuah bentuk perlawananuntuk memperoleh pengakuan status, sampai dengan tingkat perangkat hukum legal. Hal ini juga mencakup perkawinan antar sesama gay, homoseksual atau lesbian dan hukum pengangkatan anak. Selain itu, adapula kasus dari sejumlah tentara gay Amerika yang menuntut legalitas keberadaannya di institusi militer secara formal. Karena pada dasarnya, seorang gay tidak diizinkan menjadi tentara. Untuk itu Amerika -telah mengubah kebijakan Presiden sebelumnya untuk mengusulkan keberadaan gay dalam korps militernya. Lebih lanjut, pada masyarakat manapun, realitas keberadaan gay, homoseksual, atau lesbianisme merupakan kenyataan. Perbedaannya adalah sampai tingkat mana mereka mengaktualisasikannya dan cara mereka berbeda. Di masyarakat yang cenderung konservatif, realitas "penyimpangan" muncul atau ada dalam rubrik-rubrik konsultasi psikologis, konsultas seks, dan dalam wacana-wacana pinggiran. Penetrasi budaya global memungkinkan wacana-wacana pinggiran itu semakin mengemukan.

\section{LGBT DALAM PERJALANAN SEJARAH PERADABAN MANUSIA}

\section{LGBT dalam Kajian Historis}

Sebelum adanya LGBT, manusia sudah terlebih dahulu terlanjur berambisi akan daya tarik kekuasaan dan harta. Mereka kemudian menjadi serigala bagi manusia lainnya (bomo homini lupus) yang ditandai dengan penaklukan wilayah melalui jalan peperangan. Setelah perang berakhir, kaum pemenang akan memperbudak mereka yang kalah untuk kemudian digunakan tenaga dan pemikirannya melayani kaum pemenang. Namun, budak yang sudah dikalahkan biasanya kembali melakukan perlawanan (pemberontakan) yang berujung pada jatuhnya korban. Sehingga dimulailah tradisi untuk mengkibiri kelamin musuh yang telah dikalahkan.

Adanya agama yang menuntut kepatuhan dan pelayanan hidup hanya untuk Tuhan., semisal dalam istilah gereja adalah selibat (tidak kawin), maka pada kaum Galli yang menyembah dewi Cybele penyelewengan dalam ajaran agama, menyebabkan praktik pengkebirian kelamin menjadi sesuatu yang legal. Dalam Al-kitab kaum yang dikebiri ini kemudiandikenal dengan istilah sida-sida yang diantara mereka berasal dari bangsa Yahudi.

Pada masa kekaisaran Cina, terdapat kaum pelayan yang setia dan dikenal dengan istilah kasim atau thaikam. Keberadaan mereka telah ada sejak kurang lebih delapan abad sebelum masehi. ${ }^{3}$ Kasim adalah laki-laki yang telah dikebiri alat kelaminnya lalu dipekerjakan sebagai

${ }^{1}$ Ubed Abdilah S. 2002. Politik Identitas Etnis: Pergulatan Tanda Tanpa Identitas. Magelang: Yayasan IndonesiaTera. hlm. 60-61.

2 Mohamad Saleeh Rahamad. 2014. Sastera Teras Negara Bangsa. Kuala Lumpur: Institut Terjemahan \& Buku Malaysia Berhad. Hlm. 215.

${ }_{3}^{3}$ Gavin Menzies. Terj. Tufel Najib Musyada. 1421 Saat China Menemukan Dunia, (Jakarta: Pustaka Alvabet. 2002), hlm. 17. 
pelayan istana. ${ }^{1}$ Gavin Menzies (2002: 17) menyebutkan bahwa kasim memerankan peranan yang penting sepanjang sejarah China. Mereka amat loyal kepada kaisar yang telah mengesahkan pengebiriaan mereka. Biasanya para kasim bertugas untuk menjaga kerabat terdekat kaisar yang perempuan, termasuk tempat tinggal yang dihuni oleh para selir, 'Great Within'. Lakilaki yang bukan berasal dari golongan kasim dan kerabat kaisar dilarang keras memasuki kompleks istana yang telah dijaga sejumlah pasukan khusus. Jika melanggar konsekuensinya pelaku dapat dihukum berat. Ketidak adaannya laki-laki subur dalam kompleks istana menjadikan anak-anak yang lahir dari para selir Kaisar dapat dipastikan adalah anak yang berasal dari dari keturunan kaisar.

Pada masa kepemimpinan Kaisar Yongle atau Zhu Di (1403 - 1424), Cheng Ho atau Zheng He menjadi kasim, Muslim fenomenal yang melakukan tujuh ekspedisi dalam rangka mengelilingi dunia. Cheng Ho yang bernama asli $\mathrm{Ma} \mathrm{He},{ }^{2}$ juga dikenal dengan sebutan San Bao (tiga harta karun), merujuk pada tiga raisons d'etre bagi kaum Budha: Budha, doktrin dan meditasi. ${ }^{3}$ Dalam pengakuan pelayanan mereka kepada kaisar, dan tokoh yang paling berkuasa Cheng Ho adalah Kasim Agung yang terbilang sukses dalam sejarah. ${ }^{4}$

Demikian halnya dengan Kekaisaran China, dimasa Kekaisaran Ottoman (Turki Utsmani) banyak urusan yang terkait para harem (selir) didelegasikan pada para kasim dan pengawas yang berasal dari kalangan wanita. Sehingga di dalam kompleks istana hanya terdapat perempuan senior dan laki-laki bergelar Nubian, yang sudah dikebiri, dengan tugas khusus untuk mengatur semua perempuan di harem. ${ }^{5}$ Goodwin (dalam Fatwa El Guindi, 2005: 66-67), menyatakan bahwa para kasim selalu menyertai putri mahkota, mereka adalah satu-satunya kaum pria yang dapat tinggal di lingkungan harem. Dari tingkatan inilah para pejabat tinggi kekaisaran lahir.

Tidak hanya berperan sebagai pelayan ada juga golongan kaum homoseksual yang berprofesi sebagai prajurit. Sebut saja Sacred Band of Thebes atau lebih dikenal dengan istilah Theban, sebuah pasukan elite Yunani yang anggotanya berasal dari kaum yang homo berpasangan. Keberadaan pasukan ini sangat membantu Negara Kota Yunani dalam mempertahankan diri dari serangan ke negara kota yang lain. Bahkan pada perang Leuctra tahun 371 SM, pasukan Theban tercatat memiliki prestasi gemilang karena telah berhasil memukul mundur pasukan negara kota Sparta yang terkenal sangat kuat dan terdiri dari priapria macho.

Keberadaan pasukan Theban berbeda dengan para satria Amazon yang semuanya adalah perempuan. Hiasan ukiran dinding di Parthenon juga mencatat peperangan melawan suku Amazon, sebagai kelompok prajurit perempuan yang pertama mengendarai kuda di medan

1 Sisa alat kelamin yang dipotong atau disebut dengan 'bao', merupakan harta yang sangat berharga bagi seorang kasim dan harus disimpan ditempat yang aman untuk dikuburkan kembali bersama mereka. Tanpa bao, seorang kasim dikehidupan berikutnya (reinkarnasi) tidak akan menjadi laki-laki kembali.

${ }^{2}$ Cheng Ho pada awalnya berasal dari suku Hui yang sebangsa dengan suku Han di wilayah propinsi Yunnan, Namun mayoritas suku ini adalah Islam. Pada masa tersebut kaum kasim sekali lagi menjadi kekuatan politik.

${ }^{3}$ Gavin Menzies, Op. Cit, hlm. $21-22$.

${ }^{4}$ Gavin Menzies (2002: 22), meyebutkan bahwa Cheng Ho telah menyimpan penisnya yang kearas di dalam kuil sebagai peraturan yang wajib diikuti oleh seleuruh kasim. Peti yang berisi pao - harta karun kejantanan' - akan menemaninya menuju kehidupan berikutnya, dimana dia sekali lagi bisa menjadi laki-laki normal. Namun dalam kehidupannya di dunia kini, dia telah disumpah untuk melayani dan mematuhi perintah patron dan penguasa, Kaisar Ming Ketiga, Zhu Di.

${ }^{5}$ Elizabeth Abbott. Terj. Anik Soemarni. Wanita simpanan: Kontroversi Selingkuhan Tokoh-Tokoh Dunia, dari Orang Suci hingga Politis, dari Zaman Kuno hingga Era Kini, (Jakarta: Pustaka Alvabet. 2010), hlm. 54.

${ }^{6}$ Fadwa El Guindi. Terj. Mujiburohman. Jilbab: Antara Kesalehan, Kesopanan, dan Perlawanan. (Jakarta: PT. Serambi Ilmu Semesta. 2005), hlm. 66-67. 
perang. Satria Amazon bukanlah sekumpulan kaum lesbian, seorang anggota suku Amazon harus membunuh seorang laki-laki sebelum perempuan itu diizinkan menikah. ${ }^{1}$

Lebih lanjut kisah kaum homoseksual dapat ditemukan dalam berbagai literatur yang menulis sejarah manusia di masa lampau termasuk dalam sejarah-sejarah kitab suci. Dalam ajaran nasrani dan Yahudi kita mengenal praktik kaum shodom, dalam Islam kita mengenal mereka dengan umat Nabi Luth.bahkan tradisi ini muncul kembali di masa kerajaan kerajaan Eropa. Dimana Stuart King James VI of Scotland yang dikenal sebagai King James I of England, termasuk ke dalam tokoh kotroversial, karena pada satu sisi atas jasanya mempelopori penulisan Bible "King James Version", sehingga menjadi seorang yang sangat dihormati dan mendapat julukan mulias sebagai "Defender of Faith" (sang pembela agama). Namun disisi lain sejarawan Barat, Phillip J, Adler menyebutnya sebagai seorang yang arogan dan pelaku homoseks yang terang-terangan (blatant homosexua).

Majalah Historia menyebutkan bahwa pada tahun 1824 terjadi kehebohan di Keraton Surakarta. Seorang selir, dengan memainkan peran maskulin, kedapatan berhubungan seks dengan selir lainnya. Pakubuwono V juga menemukan para selirnya melakukan masturbasi bersama dengan menggunakan lilin yang dibentuk seperti alat kelamin laki-laki. Sejak itu dia tak memperbolehkan para selirnya tidur dalam ruang tertutup. Dia memerintahkan agar para selirnya tidur di depan kamarnya setiap malam. Mereka berbaring berjajar dalam masing-maisng berjarak enam kaki. Pakubuwono V rupanya khawatir para selirnya akan lebih menyukai bentuk aktivitas seksual “alternatif” itu alih-alih berhubungan dengan laki-laki. Skandal itu, sebagaimana dikutip Saskia Wieringa dan Evelyn Blackwood dalam antologi Hasrat Perempuan, dicatat penerjemah Belanda yang dekat dengan kalangan keraton Surakarta, JW Winter, pada $1902^{2}{ }^{2}$

Pada masyarakat modern, kaum homoseksual banyak berperan dalam berbagai sektor kehidupan. Alaa Al Aswany (2002: 201) menyebutkan bahwa Seorang homoseks biasanya pandai dengan pekerjaan yang mengaikat dirinya dengan banyak khalayak lain, misalnyaaktor, pengacara, dan sebagainya. Kunci suskses di balik itu adalah merek bukan jenis pemalu, disamping kehidupan abnormal memang dapat memberikan pengalaman-pengalaman hidup yang beragam, unik dan tak biasa. Barangkali inilah penyebab mereka lebih memahami karakter manusia dan mampu menarik simpati mereka. Seorang homo seks juga pandai bekerja dalam bidang yang mengandalkan intuisi dan imajinasi, seperti halnya dekorasi, desain dan tata rias. Bahakan beberapa desainer terkenal di Mesir adalah para homoseks. Barangkali karena tabiat seksual yang ganda memungkinkannya merancang berbagai busana yang menaraik laki-laki dan perempuan. ${ }^{3}$

Sikap banci jelas sangat meresahkan, seperti halnya keberadaan banci itu sendiri. Padahal menurut agama, awalnya manusia diciptakan Tuhan hanya sebagai lakilaki atau perepuan, dan hukum agaa hanya member dan minta ketegasan pilihan bagi manusia hanya menjadi pria atau wanita saja. Bukan menjadi banci! Tidak ada pilihan tengah! Agama tak menoleransi keagamaan indentitas gender, lantaran akan merusak tatanan alam dengan mendorong hubungan seks sejenis

${ }^{1}$ Jonathan Black. Terj. Isma B. Soekato dan Adi Toha. Sejarah Dunia yang Disembunyikan, (Tangerang: PT.Pustaka Alvabet. 2007), hlm. 132. 133.

2 http://historia.id/budaya/di-balik-tembok-keraton, diakses tanggal 20 April 2016. Pukul 11:36 WIB.

${ }^{3}$ Alaa Al Aswany. Terj. Anis Masduki. Apartemen Yacoubian, (Jakarta: PT. Serambi Ilmu Semesta. 2002), hlm. 201. 
yang merusak sistem sosial, sistem hukum, menyebarkan berbagai penyakit menular dan sebagainya".

\section{LGBT di Berbagai Belahan Dunia}

Penyebaran LGBT beserta aktivitas hubungan seksualnya telah mendapat legitimasi dari beberapa negara maju dan berkembang. Tercatat ada 23 negara di dunia yang memfasilitasi serta melegalkan pernikahan sesama jenis, antara lain: Norwegia (1993), Belanda (1996), Belgia (2003), Spanyol (2005), Kanada (2005), Swedia (2008), Portugal (2009), Meksiko (2009), Islandia (2010), Argentina (2010), Uruguay (2010), Selandia Baru (2013). Perancis (2013), Denmark (2013), Inggris dan Wales (2013), Skotlandia (2014), Brazil (2013), Luksemburg (2014), Finlandia (2014), Irlandia (2015). Teranyar yakni pada tahun 2015 negara adidaya, Amerika Serikat di masa pemerintahan Barack Obama turut melegalkan hubungan pernikahan sesama jenis.

Di Indonesia kaum LGBT mulai lebih vulgar menunjukan eksistensinya dengan didukung di muka publik. Hal ini didukung oleh keberadan media sosial termasuk media cetak dan elektronik. Pelaku LGBT telah membuktikan media masa adalah instrument yang paling ampuh dalam merubah paradigma dan penerimaan masyarakat terhadap mereka. Hal ini ditunjukkan dengan adanya perayaan Gay Pride (Bangga Menjadi Gay) pertama yang pernah dilangsungkan di Indonesia pada tanggal 25 Juni 1999 di Surabaya. Selain itu gerakan bawah tanah (underground) untuk mendapat simpati yang lebih besar dari publik juga dilakukan melalui penerbitan novel bergenre LGBT, testimoni penderitaan kaum LGBT, serta mengajak masyarakat melihat perkembangan LGBT yang telah diterima oleh negara-negara maju. Padahal secara historis latar belakang kelahiran bangsa dan budaya Eropa dan Amerika berbeda dengan budaya luhur ketimuran.

Berdasarkan hasil jajak pendapat yang dilakukan harian Jawa Post terhadap empat ratus mahasiswa Surabaya, diperoleh informasi bahwa sebanyak $78 \%$ responden tidak setuju dengan keberadaan gay sedangkan $22 \%$ memilih jawaban setuju. Selanjutnya terdapat 54,0 \% reponden yang mengaku bersikap biasa saja menaggapi orang yang memproklamirkan dirinya sebagai gay, sedangaan 25,6 \% mengaku memilih untuk menjauhi, dan sisanya atau 20,4\% memilih untuk membimbingnya agar kembali normal. Ketika ditanya tentang organisasi gay di Indonesia, 90,8 \% reponden memilih jawaban tidak tahu, sedangkan 9,2\% menjawab bahwa dirinya tahu. ${ }^{2}$

Meskipun LGBT disebagian negara berkembang. Namun tidak semua pelakunya hidup permanen dengan idealismenya. Sam Brodie seorang aktor dan presenter kelahiran Medan 1987 yang terkenal dalam acara reality show 'Living the Dream' dan 'Big Brother 7 UK' pada akhirnya memulih untuk menjadi muallaf dan kembali menjadi laki-laki normal setelah bertahun-tahun hidup menjadi perempuan. Bahkan Sam Brodie telah menikah dengan perempuan dan dikarunia anak dari pernikahnnya tersebut.

\section{LGBT DALAM KAJIAN AGAMA}

Keberadaan LGBT dalam komponen atau istilah-sitilah yang terpisah telah diceritakan dalam berbagai kitab suci. Dalam tradisi Hindu, Srikandi yang kelak bertempur dalam melawan Bhisma dalam perang Bharatayuda di padang Kurukshetra adalah Amba yang telah lahir kembali dalam wujud perempuan. Nyoman S. Pendit (2010: 31) meyebutkan bahwa lama kelamaan, kelamin putri Raja Drupada itu berubah. Ia menjadi seorang laki-laki dan kemudain termasyhur

\footnotetext{
${ }^{1}$ Yonathan Rahardjo. Taman Api. (Jakarta: Alvabet. 2011), hlm. 23.

2 Abu Ameenah Philips dan Zafar Khan, Islam dan Homoseksual, (Jakarta: Pustaka Zahra, 2003), hlm. 79.
} 
dengan nama Srikandi, artinya "pahlawan perang". Selain itu dalam tradisi Budha, dewi Kwan Im (Avalokitesvara) sebelum reinkarnasi sebagai sosok seorang dewi, merupakan laki-laki dalam kehidupan sebelumnya.

Islam tidak phobia terhadap LGBT, bahkan Islam memberikan pengakuan terhadap keberadaan kaum LGBT sebagai sebuah realitas kehidupan manusia. Misalnya dalam segi ibadah shalat berjamaah, mereka yang termasuk kategori layaknya sifat seorang banci dibenarkan menjadi imam bagi kaum perempuan dan anak-anak, tetapi tidak berlaku untuk mengimami laki-laki. Selain itu, tidak ada aturan dalam Islam bagi mereka yang memiliki sifat kebanci-bancian untuk tidak mendapatkan zakat, sedekah ataupun bahkan warisan.

Toleransi Islam pada kaum LGBT, hanya sebatas pada sikap, perilaku dan pemikiran mereka dalam kehidupan. Namun dalam segi aktivitas seksual, bagi pelaku LGBT, hal ini terkategorikan sebagai suatu perbuatan zina dan perbuatan melanggar hukun negara Republik Indonesia karena tidak syahnya hubungan badan mereka secara hukum. Dalam hal ini hanya mengakui seks dalam lembaga pernikahan antara laki-laki dan perempuan yang seagama, sebagaimana tertuang dalam 1 Tahun 1974 tentang perkawinanyang diartikan sebagai ikatan lahir bathin antara seorang pria dengan seorang wanita sebagai suami isteri dengan tujuan membentuk keluarga (rumah tangga) yang kekal berdasarkan ketuhanan Yang Maha Esa.2

Anang Harris Hermawan (2007: 72) menyebutkan bahwa dalam Islam homoseksual sebagai perbuatan keji (fahisyah), hal ini sebagaimana terdapat dalam QS. Al-A;raf: 80 dan bagian dari zina. ${ }^{3}$ Menurut Ukasyah Athibi (1998: 371), perbuatan keji (al-fahisyah) adalah perbuatan yang mencapai tingkat paling kotor dan hina, sangat terkutuk, dan tercela. Jiwa yang masih suci dan perasaan yang masih murni tidak akan bisa menerimanya. ${ }^{4}$ Karena itu Allah SWT memperingatkan supaya manusia jangan menghampiri perbuatan keji tersebut, baik yang nyata ataupun terselubung.

Menurut Ibn Majah, At-Tirmidzi dan Al-Hakim (dalam Danial Zainal Abidin. 2015: 345) Nabi Muhammad SAW, bersabda, "Perkara yang paling aku takuti menimpa kepadamu adalah perbuatan kaum Nabi Luth. Dilakanat mereka yang melakukan perbuatan seumpama kaum Luth". Karena sedemikian menjijikannya perbuatan tersebut Rasulullah SAW., pun mengharmkannya dan menetapkan hukum mati bagi para pelakunya. Sebagaimana sabda beliau, "Apabila seorang pria mendatangi (berbubungan badan) dengan pria maka keduanya bervina. Dan apabila seorang perempuan mendatangi (berhubungan badan) dengan perempuan, keduanya pun berzina.

Barangsiapa kamu dapati melakukan perbuatan kaum Luth, bunublah pelaku dan penerima perlakuannya. (HR. Turmudzi dan Nasa'i). ${ }^{6}$

${ }^{1}$ Nyoman S. Pendit. Mahabarata, (Jakarta: PT. Gramedia Pustaka Utama. 2010), hlm. 31.

${ }^{2}$ Gus Arifin, Menikah Untuk Bahagia: Figh Tentang Pernikahan dan Kamsutra Islami, (Jakarta: PT. Elex Media Komputindo. 2010), hlm. 89.

${ }_{3}^{3}$ Anang Harris Hermawan, Bukan Salh Tuban Mengazab: Ketika Perzinaan Menjadi Berbala Kebidupan, (Solo: Tiga Serangkai. 2007), hlm. 72.

${ }^{4}$ Ukasyah Athibi. Terj. Chairul Halim. Wanita Mengapa Merosot Akblaknya, (Jakarta: Gema Insani Press, 1998), hlm. 371.

${ }^{5}$ Danial Zainal Abidin. Perubatan Islam dan Bukti Sains Modern, (Selangor, Malaysia : PTS Millennia SDN. BHD. 2015), hlm. 345.

${ }^{6}$ Adnan Tharsyah. Terj. Arum Tirta Sari. 16 Jalan Kebahagian Sejati. (Jakarta: PT Mizan Publika. 2006), hlm. 31. 
Keberadaan LGBT untuk saat ini bukanlah ancaman bagi masayarakat Indonesia. Namun membiarkan keberadaan pengikut fanatik kaum Sodom dibalik gerakan LGBT. Mesti menjadi perhatian semua pihak termasuk para pemangku kebijakan di pusat maupun daerah untuk segara melakukan tindak tegas terhadap para pelakunya. Hal tersebut dalam rangka menjamin eksistensi keberadaan manusia yang bermartabat, sekaligus sesuai dengan kodratnya sebagai ciptaan Tuhan untuk dapat hidup normal dan berpasangan sebagaimana mestinya. Selain itu, keberadaan LGBT dalam perdaban manusia secara nyata lebih banyak mendatangkan mudharat ketimbang manfaatnya.

Kaum LGBT yang melegalkan dan melakukan hubungan seks sesama jenis, menjadi sebuah wabah kronis di masyarakat ketika mereka menjadi LGBT aktif yang kemudian berusaha dengan segenap tenaga mencari korban baru dengan uang dan kekuasaan yang mereka miliki. Dengan cara ini ditambah rasa malu pada korban yang telah. Kemudian dari terlebih hubungan suka sama suka dalam hukum tidak dijatuhi hukuman pidana.

Selain itu dengan hadirnya kelompok LGBT, keberlangsungan umat manusia dimuka bumi tidak akan lagi berlangsung lama, selain menuju kepunahan seiring meningkatnya jumlah pelaku LGBT. Pasangan sesama laki-laki yang yang memiliki kromosom sel yang sama tidak akan pernah bisa saling membuahi dan menjadi individu yang baru. Kalaupun teknologi baru dari masa depan berhasil mengawinkan kromosom sel yang sama maka mereka harus menemukan rahim wanita yang bukan pasangan LGBT-nya. Hal ini justru membuka persoalan baru dan tindakan keji yang lebih hina dari pada yang dilakukan oleh binatang. Ini juga berlaku pada kaum pecinta sesama jenis yang berasal dari sesama pasangan berjenis kelamin perempuan.

Di Indonesia saat ini belum ada lembaga yang memiliki data akurat mengenai jumlah pelaku LGBT pengidap penyakit kelamin dan menular. Seperti HIV/AIDS, sipilis, gonorboe, hepatitis, dan lain-lain. Menurut Ferry Effeni dan Makhfudli (2009: 225) menyatakan bahwa pola penyebaran HIV/AIDS di Indonesia tak jauh berbeda dengan negara-negara lain. Fase awal penyebarannya adalah melalui kelompok homoseksual kemudian tersebar melalui perilaku seksual berisiko tinggi seperti pekerja seks komersial. ${ }^{1}$ Aktivitas seksual yang dilakukan secara oral maupun anal yang dilakukan kaum homoseksual merupakan bentuk penyimpangan orientasi seksual yang berakibat buruk pada kesehatan. Sebab, manusia pada dasarnya diciptakan dengan tujuan dan fungsi yang ditentukan, dimana kelamin laki-laki diciptakan untuk sesuai dengan kelamin wanita.

Adnan Tharsyah (2007) menyebutkan diantara bahaya perilaku seks kaum homoseksual diantaranya pertama, dampaknya pada saraf dimana saraf sudah tidak bekerja sebagimana mestinya dalam hal kepuasan seksual. Apa yang baik baginya dianggap buruk dan juga sebaliknya Kedua, meregangkan otot anus dan merobeknya, sehingga anus tidak mampu lagi menahan ataupun menyimpan kotoran. Bagi kaum homoseksual perempuan yang biasanya melakukan aktvitas seksual melalui oral, hal ini berdampak pada kangker rahim. Ketiga, pada laki-laki dapat membunuh spermatozoa dan menyeabkan kemandulan. ${ }^{2}$ Selain itu menurut Muhammad Nabil Kazhim (2007:

${ }^{1}$ Ferry Efendi dan Makhfudli, Keperawatan Kesehatan Komunitas: Teori dan Praktik dalam Keperawatan, (Jakarta: Penerbit Salemba Medika. 2009), hlm. 225.

2 Adnan Tharsyah. Terj. Arum Tirta Sari. 16 Jalan Kebahagian Sejati, (Jakarta: PT Mizan Publika. 2006), Hlm. $31-32$. 
190) perilaku kebanci-bancian, zina dan homo seksual serta berbagai konsepsi lainnya, hanya mengotori pendidikan seksual yang benar.

\section{PENUTUP}

Berdasarkan berbagai penjelasan di atas, LGBT beserta segala bentuk dan aktivitasnya, bukanlah merupakan hal yang asing terutama jika dipadang dalam perspektif ajaran agama khususnya Islam. Sepak terjang mereka dalam berbagai peristiwa sejarah juga nampak jelas mewarnai perdaban manusia hingga millennium ke tiga. Mulai dari peñata busana, tata rias, desainer hingga prajurit. Namun tak sedikit pula yang aktif dan terjerumus dalam dunia prostitusi, peredaran narkoba sampai tindakan kriminal lainnya.

Keberadaan orang yang teridentifikasi bagian dari LGBT bukanlah berarti menjadikan mereka harus dibenci, dimusuhi, diasingkan atau bahkan dianiaya. Mereka hendaknya tetap dihargai sesuai kodratnya sebagai makhluk ciptaan Tuhan, sekaligus bagian dari dinamika kehidupan manusia di muka Bumi.

Tidak semua anggota LGBT merupakan kaum loyalis yang memegang ideologi hingga akhir kehidupannya. Sebagian diantarnya justru dapat disembuhkan dan kembali hidup normal, bahkan diantaranya menikah serta memiliki keturunan. Proses pendidikan dan perlakuan yang sesuai dengan kodratnya, penerimaan dan keikhlasan diri terhadap apa yang dimiliki, serta keyakinan akan keadilan anugrah yang telah diberikan Tuhan akan menjadi akumulasi dari keraguan dan penolakan tentang apa yang telah terjadi pada dirinya.

\section{REFRENSI}

Abbott, Elizabeth. Terj. Anik Soemarni. 2010. Wanita simpanan: Kontroversi Selingkuban Tokob-Tokoh Dunia, dari Orang Suci bingga Politis, dari Zaman Kuno bingga Era Kini.Jakarta: Pustaka Alvabet.

Abidin, Danial Zainal. 2015. Perubatan Islam dan Bukti Sains Modern. Selangor, Malaysia : PTS Millennia SDN. BHD.

Al Aswany, Alaa. Terj. Anis Masduki. 2002. Apartemen Yacoubian. Jakarta: PT. Serambi Ilmu Semesta.

Arifin, Gus. 2010. Menikah Untuk Bahagia: Fiqh Tentang Pernikahan dan Kamsutra Islami. Jakarta: PT. Elex Media Komputindo.

Athibi, Ukasyah. Terj. Chairul Halim. 1998. Wanita Mengapa Merosot Akblaknya. Jakarta: Gema Insani Press.

Black, Jonathan. Terj. Isma B. Soekato dan Adi Toha. 2007. Sejarah Dunia yang Disembunyikan. Tangerang: PT.Pustaka Alvabet.

Efendi, Ferry dan Makhfudli. 2009. Keperawatan Kesehatan Komunitas: Teori dan Praktik dalam Keperawatan. Jakarta: Penerbit Salemba Medika.

Guindi, Fadwa El. Terj. Mujiburohman. 2005. Jilbab: Antara Kesalehan, Kesopanan, dan Perlananan. Jakarta: PT. Serambi Ilmu Semesta.

${ }^{1}$ Muhammad Nabil Kazhim. Terj. Ibnu Abdil Jamil. Buku Pintar Nikah: Strategi Jitu Menuju Pernikahan Sukses, (Solo: Samudera. 2007), hlm. 190. 
Hermawan, Anang Harris 2007. Bukan Salh Tuban Mengazab: Ketika Perzinaan Menjadi Berbala Kehidupan. Solo: Tiga Serangkai.

http://historia.id/budaya/di-balik-tembok-keraton, diakses tanggal 20 April 2016. Pukul 11:36 WIB.

Kazhim, Muhammad Nabil. Terj. Ibnu Abdil Jamil. 2007. Buku Pintar Nikah: Strategi Jitu Menuju Pernikahan Sukses. Solo: Samudera.

Menzies, Gavin. Terj. Tufel Najib Musyada. 2002. 1421 Saat China Menemukan Dunia. Jakarta: Pustaka Alvabet.

Pendit, Nyoman S. 2010. Mahabarata. Jakarta: PT. Gramedia Pustaka Utama.

Philips, Abu Ameenah dan Zafar Khan. 2003. Islam dan Homoseksual. Jakarta: Pustaka Zahra.

Rahamad, Mohamad Saleeh. 2014. Sastera Teras Negara Bangsa. Kuala Lumpur: Institut Terjemahan \& Buku Malaysia Berhad.

Rahardjo, Yonathan. 2011. Taman Api. Jakarta: Alvabet.

S. Ubed Abdilah. 2002. Politik Identitas Etnis: Pergulatan Tanda Tanpa Identitas. Magelang: Yayasan IndonesiaTera.

Tharsyah, Adnan. Terj. Arum Tirta Sari. 2006.16 Jalan Kebahagian Sejati. Jakarta: PT Mizan Publika. 